() Entomologica Fennica. 12 December 1994

\title{
Heteroptera from Socotra
}

\author{
Rauno E. Linnavuori
}

Linnavuori, R. E. 1994: Heteroptera from Socotra. - Entomol. Fennica 5:151-156.

A list of Heteroptera species from Socotra is published. Three new species of Miridae are described: Peritropis selene sp. n., Yotvata (Yotvata) erifyle sp. n., and Yotvata (Godataira) hadibo sp. n.

Rauno E. Linnavuori, Somersoja, FIN-21220 Raisio, Finland

Received 25 August 1993, accepted 1 October 1993

\section{Introduction}

Very few records have been published on the Heteropteran fauna of Socotra. Brown (1956) treated the aquatic and subaquatic groups. Articles on the terrestrial Heteroptera were published by Distant (1903), Kirkaldy (1899 and 1903) and Linnavuori (1989). Dr. Antonius van Harten, of the Yemeni German Plant Protection Project, Sana'a, Republic of Yemen, visited Socotra in April 1993 and collected a small but interesting collection of Heteroptera, which included, besides several species not previously recorded from Socotra, three mirid species new to science. Judging from the material and the previous records, the fauna of Socotra is predominantly Ethiopian. In contrast, only a few Mediterranean or Eremian species have reached the island. Isolation of the island has effectively led to speciation so that the number of endemic species is undoubtedly high.

The material studied is the property of the American Museum of Natural History, but at present kept in the author's collection.

\section{New species}

\section{Peritropis selene sp. n. (Miridae, Cylapinae)}

Fig. 1 a-e

Types: Socotra: Nogeed, $\sigma^{7}$ holotype, $1 \sigma^{7}$ and 20 paratypes, 16.IV.1993; Hadibo, o paratype, 13-14.IV.1993, Van Harten, in coll. Linnavuori.
Diagnosis: Readily distinguished by the small size, very long and gracile, apically broadly infuscate 2 nd antennal segment and the structure of the pronotum: lateral margin insinuated, basal margin with a rounded hump on each side of median insinuation, calli small. The related species, $P$. maculicornis Linnavuori \& Al-Safadi (1993:179-180) and P. armillarius Schmitz (1970:505), are larger, length in $\sigma^{7}$ (ф unknown) about $3.5 \mathrm{~mm}$. The 2nd antennal segment is shorter, the lateral margins of the pronotum are slightly curved, the basal margin is nearly even, and the calli are much larger. Moreover, in $P$. maculicornis the 2nd antennal joint (Fig. 1f) is more variegated. In $P$. armillarius (Fig. $1 \mathrm{~g}-\mathrm{h}$ ) the 2nd antennal joint is dark brown with two pale rings, and the femora and tibiae are ornamented with broad dark brown rings.

Description: Length ơ 2.75-3.0 mm. O 2.75 $\mathrm{mm}$. Whitish ochraceous with abundant dark brown irroration. Sides of apical part of head with dark markings, frons with faint brown lateral arcs, median line and the raised basal margin of vertex with minute red dots; eyes brown. 1st antennal joint whitish with blackish markings, 2nd whitish with 3 blackish brown rings, the apical ring remarkably brown, joints 3 and 4 blackish brown. Pronotum with dense dark brown irroration, calli and middle of apical margin more sparsely irrorate, often ornamented with minute reddish dots. Scutellum with dense dark irroration, 


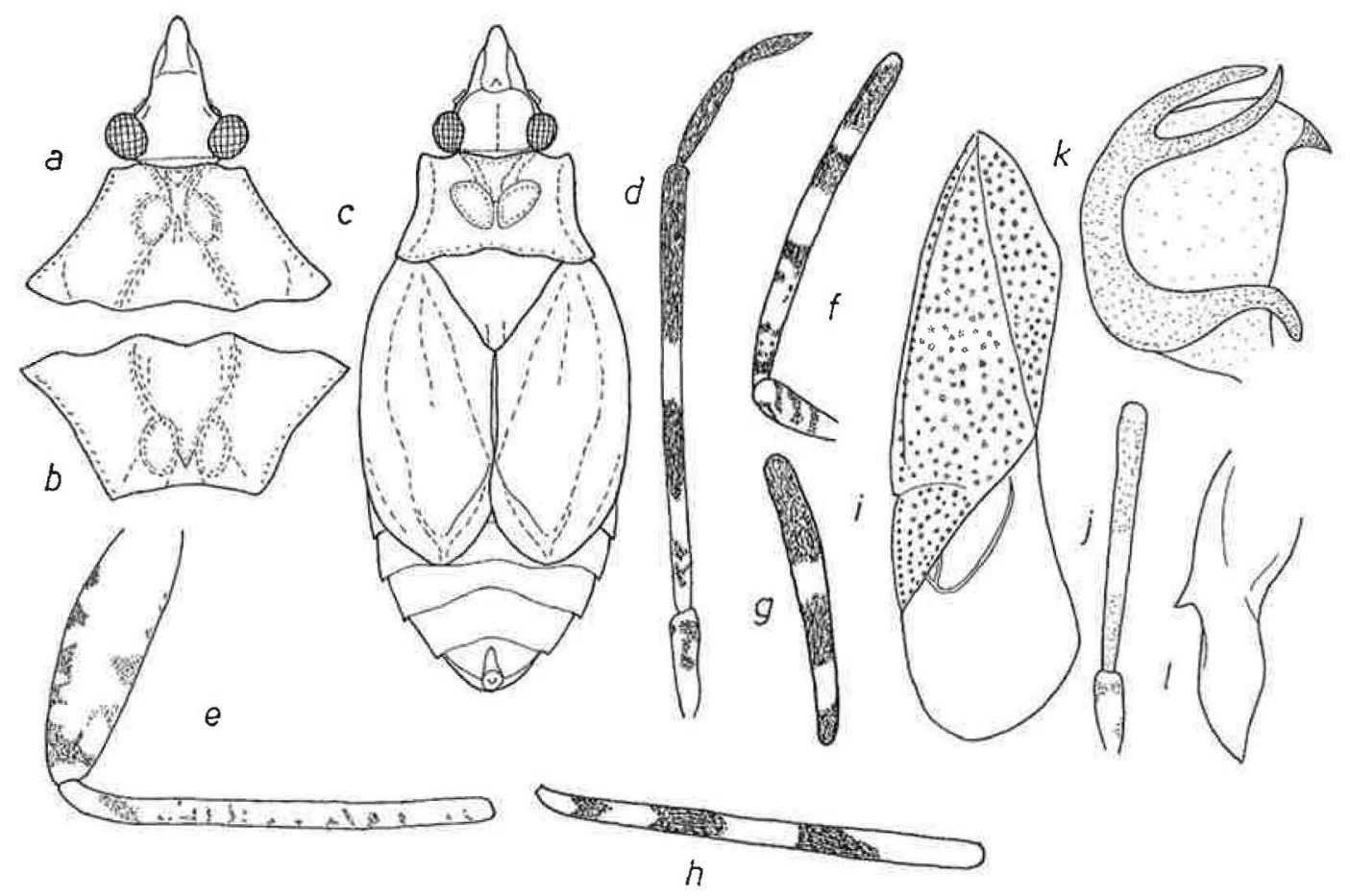

Fig. 1. Peritropis selene sp. $n$. a: male head and pronotum in dorsal view; $b$ : male pronotum in apicodorsal view; c: female; d: male antenna; e: hind femur and tibia. - P. maculicornis Linnavuori \& Al-Safadi. f: 1 st and 2nd antennal segments. $-P$. armillarius Schmitz. g: 2nd antennal segment; $\mathrm{h}$ : hind tibia. - Yotvata erifyle sp. $\mathrm{n}$. i: elytron; j: 1st and 2nd antennal segments; $\mathrm{k}$ : left style in broad aspect (dry mount); l: theca.

apex and middle of base more sparsely irrorate. Elytra with dense brown mottling, the largest spots present on costal margins and veins; membrane brownish smoky with dense fuscous irroration. Under surface with dense confluent brown and purplish mottling. Coxae pale. Legs whitish ochraceous; femora with dense dark brown markings on apex and along margins; tibiae with dark brown dotting, densest on fore, sparsest on hind tibiae. - Dimorphic. $0^{7}$ macropterous. Body elongately ovate, $2.7 \times$ as long as broad at base of pronotum. $q$ brachypterous. Body elongately pyriform, $3.2 \times$ as long as broad at base of pronotum, broadest at middle of abdomen. Hair covering short, scale-like, whitish. Head 0.6 $\left(0^{7}\right)$ or $0.7(Q) \times$ as broad as basal width of pronotum, in apical view slightly longer than broad, in lateral view $1.34\left(\sigma^{7}\right)$ or $1.67(\odot) \times$ as long as high; frons moderately convex, vertex with faint median depression and raised hind margin; ocular index $1.40\left(0^{\top}\right), 2.11-2.38$ (Q).
Antennae long and gracile, hair covering short, pale, on joints 3 and 4 a little longer; proportions between joints 16:72:15:13 $\left(\sigma^{\top}\right), 17: 80: 15: 12(Q)$, 1 st joint ( $\sigma^{\prime} \emptyset$ ) $0.41-0.43 \times$ as long as diatone, 2 nd very long, $1.85\left(\bigcirc^{7}\right)$ or $2.1(Q) \times$ as long as diatone, $1.1\left(\sigma^{7}\right)$ or $1.45(\phi) \times$ as long as basal width of pronotum, 3rd joint $\left(\sigma^{\top} Q\right) 0.2 \times$ as long as 2 nd. Rostrum extending near to pygofer. Pronotum in $\sigma^{7} 2.33 \times$ as broad as long in middle, strongly broadening caudad, lateral margins insinuated, sharp and upcurved, anterolateral angles blunt, humeral angles sharp; anterior margin undulating with sublateral expansions and shallow median insinuation; basal margin undulating, with rounded hump on each side of median insinuation; calli small, elevated, separated from each other by depression, a ridge extending from each callus to the corresponding hump of basal margin. Pronotum in $Q 2.2 \times$ as broad as long in middle, trapezoidal; lateral margins insinuated, subparallel in anterior part, diverging caudad basally, sharp, 


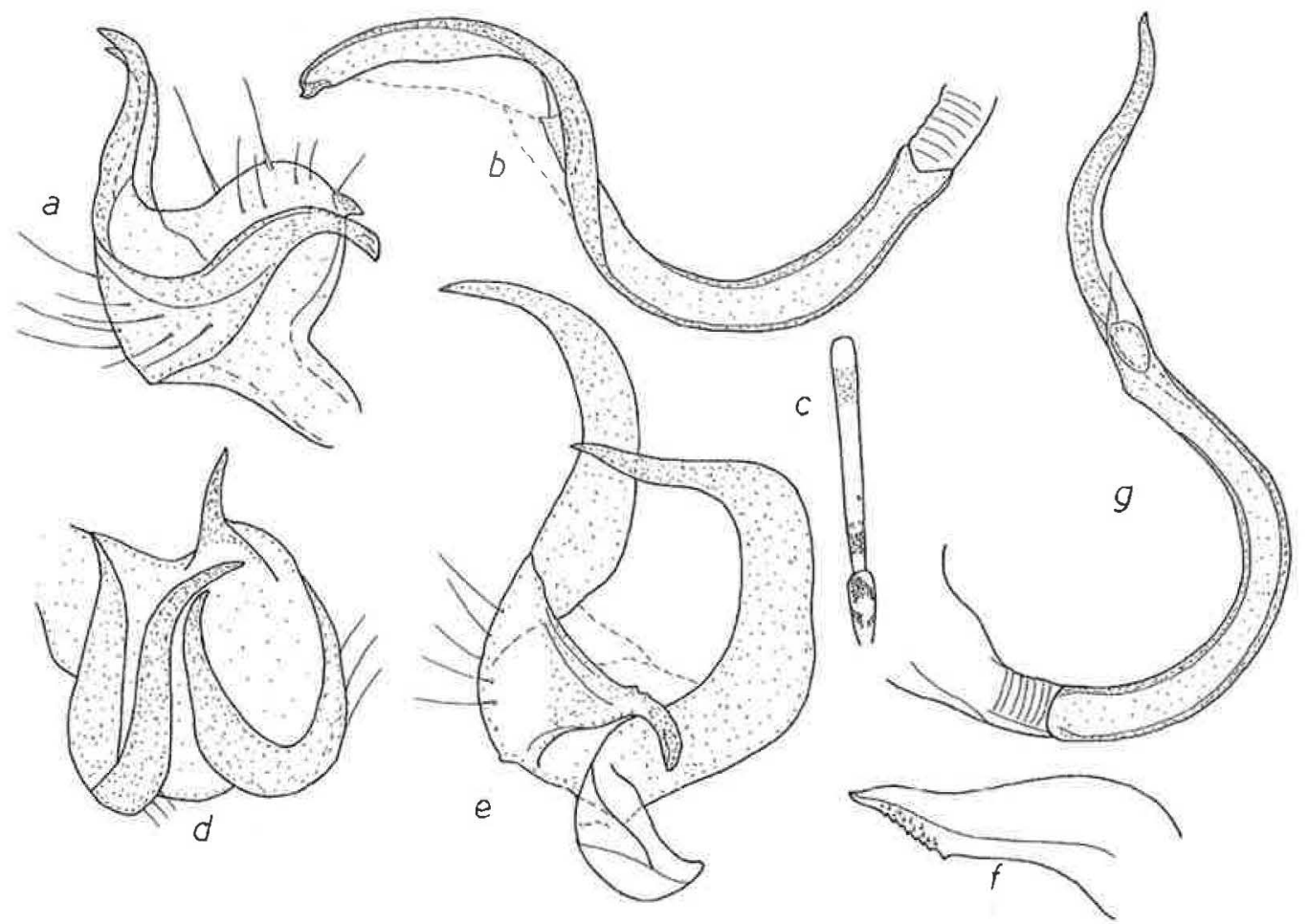

Fig. 2. Yotvata erifyle sp. n. a: left style (slide mount); b: vesica (slide mount). $-Y$. hadibo sp. n. c: 1st and 2nd antennal segments; d-e: left style in dry mount (broad aspect) and slide mount; f: theca; g: vesica (slide mount).

upcurved, anterolateral and humeral angles prominent; anterior margin undulating as in $0^{\text {; }}$; basal margin undulating with only rounded elevation on each side of median excavations; calli relatively strong, conical, separated from each other by median sulcus. Elytra in $O^{\top}$ longer than abdomen, in $\circ$ much shorter, ovate in outline, coriaceous, without membrane rudiments. Hind tibia $1.21\left(\mathrm{O}^{7}\right)$ or $1.7(\mathrm{O}) \times$ as long as basal width of pronotum, tibial spines delicate, pale.

Etymology: Greek mythology, Selene, goddess of the moon.

Yotvata (Yotvata) erifyle sp. n. (Miridae, Phylinae)

Figs. 1i-1, 2a-b

Types: Socotra: Hadibo of holotype, $2 \%$ paratypes, 13-14.IV.1993, van Harten, in coll. Linnavuori.
Diagnosis: Readily distinguished by the small gracile body and unique coloring. The other species (descriptions in Linnavuori 1984:44-45, 1986:160), Y. picticornis (Horváth, 1913) (Eremian), $Y$. nergal Linnavuori, 1984 (Iraq) and $Y$. albocunealis Linnavuori, 1986 (Eremian), differ an a considerably broader body, which is ornamented with conspicuous fuscous and purplish markings both on the upper and under surface. The male genitalia are also dissimilar.

Description: Length $2.25 \mathrm{~mm}$. Whitish gray. Head with orangish lateral arcs; eyes grayish. 1st antennal joint pale yellow with faint reddish basal and apical spots; 2nd joint pale orangish, subbasal ring and extreme tip whitish; joints 3 and 4 yellow-brown. Pronotum, clavus, corium, and cuneus with dense minute fuscous dotting. Scutellum yellowish. Membranes of elytra uniformly grayish smoky, veins pale. Under surface brownish gray. Legs pale ochraceous, femora with dense fuscous mottling, tibiae with small 
dark setigerous spots, tibial spines pale. - Body very small and gracile, parallel-sided, 3.40 (Q) or $3.44\left(0^{7}\right) \times$ as long as broad at base of pronotum. Hair covering pale. Head about $0.7 \times$ as broad as basal width of pronotum; ocular index $1.53\left(\sigma^{7}\right)$, 2.14 (o). Antennae with brownish hairs; proportions between joints 11:38:19:18 $\left(\sigma^{7}\right), 12: 30: 19: 16$ $(Q)$, 2nd joint $1.27\left(0^{7}\right)$ or $1.03(Q) \times$ as long as diatone, $0.90\left(\sigma^{7}\right)$ or $0.68(Q) \times$ as long as basal width of pronotum. Rostrum extending to middle coxae. Pronotum about $2.5 \times$ as broad as long in middle. - Male genitalia (Figs. 1k-1, 2a-b): Pygofer conical. Right style very small, ovate. Left style distinctive, large, provided with a clawlike process and three long appendages, two of them lying close to each other and resembling claws of a crayfish. Theca with a tooth-like process. Vesica shallowly S-shaped, edentate, apex with a short claw-like process.

Etymology: Erifyle, daughter of Adrastos, a king in ancient Argos.

Yotvata (Godataira) hadibo sp. n. (Miridae, Phylinae)

Fig. $2 \mathrm{c}-\mathrm{g}$

Types: Socotra: Hadibo, ơ holotype, o paratype, 1314.IV.1993, van Harten, in coll. Linnavuori.

Diagnosis: The taxonomy of the subgenus Godataira Linnavuori, 1975, has been treated in Linnavuori 1975:92-93, 1984:43-45 and 1986:160-161. Y. hadibo differs from the related species Y. pulchella Linnavuori, 1975 (Sudanese) and Y. pulcherrima Linnavuori, 1984 (Iraq) in the gracile body, colouring (pronotum, scutellum and elytra orange with whitish pattern), small eyes and structure of the left style. In $Y$. pulchella and $Y$. pulcherrima the body is more broadly ovate, the pronotum, scutellum and elytra are white with separate orange spots, the eyes are larger (ocular index in Y. pulchella $0.91\left(\sigma^{7}\right)$ or 1.1 (ᄋ), in $Y$. pulcherrima $1.27-1.54$ ( $\left(^{\top}\right)$ or 1.80-1.83 (O)), and the left style is dissimilar. In the other species of Godataira, Y. aqualla Linnavuori, 1975 (Sudanese), Y. ectagela Linnavuori, 1975 (Sudanese), Y. salmana Linnavuori, 1984 (Iraq), and Y. hawtana Linnavuori, 1986 (Saudi Arabia, Yemen), the upper surface is, in addition to or- ange spots, also ornamented with fine fuscous dots.

Description: Length $2.25-2.50 \mathrm{~mm}$. Head whitish, frons with orange lateral arcs, median stripe on tylus and a few dots on base of vertex, red; eyes gray. 1 st and 2 nd antennal joints whitish ochraceous, apical ring and basal spots on the former and subbasal ring and a few very small dots on the latter, bright red, subapical part of 2nd with slight orangish tinge, joints 3 and 4 embrowned. Pronotum orange with three irregular longitudinal whitish bands, the white areas and basal margin bordered with small red spots. Scutellum orange, lateral margins whitish with small red dots. Elytra orange with irregular white markings, bordered with small red dots, on clavus, corium and cuneus, costal margins with alternating orange and white spots, inner margin of cuneus with a row of small dark spots; membrane brown with faint pale irroration, lateral margin pale with a dark triangular spot; veins pale, basal part of inner vein dark. Under surface whitish to fulvous, sides with orange and red markings. Legs absent in the specimens studied. — Body small and very gracile, $3.4\left(0^{7}\right)$ or 3.1 (Q) $x$ as long as basal width of pronotum. Hair covering pale. Head $0.7\left(\sigma^{7}\right)$ or $0.6(Q) \times$ as broad as basal width of pronotum; ocular index $1.75\left(\bigcirc^{7}\right)$, 2.46 (Q). Proportions between antennal joints 10:35:20:18 $\left(0^{7}\right), 11: 34: 19: 16(Q)$, 2nd joint $\left(\sigma^{7} Q\right)$ $1.17 \times$ as long as diatone, $0.83\left(\sigma^{\prime}\right)$ or $0.71(Q) \times$ as long as basal width of pronotum. Rostrum extending to hind coxae. Pronotum about $2.5 \times$ as broad as long in middle. - Male genitalia (Fig. 2d-g): Pygofer conical. Right style very small. Left style distinctive, with two long falcate appendages and a short middle process. Subapical part of theca finely dentate. Vesica shallowly Sshaped, sharp-tipped.

Etymology: Named after the type locality.

\section{List of species}

\section{Cydnidae}

Aethus perithrix Mancini, 1937. - Muomi, 1 ex, 16.IV.1993. - Known from Ethiopia and Somalia. 
Aethus pilosulus (Klug, 1845). - Hadibo, 1 ex, 13-14.IV.1993. — Eremian.

Macroscytus brunneus (Fabricius, 1803). Muomi, 2 exx, 15.IV.1993. - - Holomediterranean with a wide range in the Ethiopian and Oriental Regions.

\section{Pentatomidae}

Coridius viduatus (Fabricius, 1794). Hadibo, 1 ex, 13-14.IV.1993. - Nearly all Africa, the Arabian Peninsula, Egypt, Israel, Turkey, Iran.

Acrosternum millierei (Mulsant \& Rey, 1866). - Nogeed, 1 ex, 16.IV.1993. - Holomediterranean with a wide range within the Sudanese subregion in Africa.

Piezodorus rubrofasciatus (Fabricius, 1787). - 5 exx from Hadibo, 13-14.IV.1993, and Muomi, 15.IV.1993. - Paleotropical.

Alydidae

Tenosius proletarius (Schaum, 1853). Muomi, 1 ex, 15.IV.1993. - Holosudanese, extending to North Africa and the Middle East.

Nariscus spinosus (Burmeister, 1835). Hadibo, 1 ex, 13-14.IV.1993. - Eremian, extending from West Africa to Iran.

\section{Pyrrhocoridae}

Scantius forsteri (Fabricius, 1781). - Muomi, 4 exx, 15.IV.1993. - Nearly all Africa, the Mediterranean subregion, the Middle East, and India.

\section{Lygaeidae}

Camptocoris typus (Distant, 1918). - Hadibo, 1 ex, 13-14.IV.1993; Nogeed, 1 ex, 16.IV.1993. Holosudanese, extending to Yemen, Iraq and India.

Geocoris sokotranus Kirkaldy, 1899. Muomi, 2 exx, 15.IV.1993. - Endemic.

Dieuches forbesi (Kirkaldy, 1899). — Several exx from Hadibo, 13-14.IV.1993 and Muomi, 15.IV.1993. - Endemic.

Serranegra petrophila Lindberg, 1958. Nogeed, 1 ex, 16.IV.1993. - - Northsudanese, extending from the Cape Verde Islands to Yemen.
Anepsiocoris encaustus (Puton, 1869). Hadibo, 1 ex, 13-14.IV.1993. - Eremian.

Pachybrachius dubius (Reuter, 1882). Hadibo, 1 ex, 13-14.IV.1993. - Holosudanese.

Emblethis gracilicornis Puton, 1883. Nogeed, 1 ex, 16.IV.1993. - Eremian.

\section{Reduviidae}

Pirates strepitans Rambur, 1842. - Nogeed, 1 ex, 16.IV.1993. - Widespread in Africa and the Mediterranean subregion.

Coranus angulatus Stål, 1874. - Muomi, 1 ex, 15.IV.1993. — Eremian.

\section{Tingidae}

Phaenotropis cleopatra (Horváth, 1905). Hadibo, 1 ex, 13-14.IV.1993. — The Sudanese subregion from Senegal to the Sudan, Egypt, Palestine, Middle Asia, Pakistan, India.

\section{Miridae}

Peritropis selene sp. n. - 5 exx from Nogeed, 16.IV.1993 and Hadibo, 13-14.IV.1993. Socotra.

Yotvata erifyle sp. n. - Hadibo, 3 exx, 1314.IV.1993. - Socotra.

Yotvata hadibo sp. n. - Hadibo, 2 exx, 1314.IV.1993. - Socotra.

\section{References}

Brown, E. S. 1956: Aquatic Hemiptera from Socotra. -Ann, Mag. Nat. Hist. London (12)9:140-144.

Distant, W. L. 1903: Rhynchotal notes XIX. - Ann, Mag. Nat. Hist. London (7) 12:469-480.

Kirkaldy, G. W. 1899: Descriptions of ten new species of Hemiptera. - Bull. Liverpool Mus. 2:45-47.

- 1903: - In: Forbes, H. O. (ed.), The natural history of Socotra and Abd-el-Kuri expedition 1898-1899. Hemiptera: 381-394. W. R. Ogilvie-Grant and H. D. Forbes, Liverpool.

Linnavuori, R. E. 1975: Hemiptera of the Sudan, with remarks on some species of the adjacent countries 4 . Miridae and Isometopidae. - Ann. Zool. Fennici 12:1118.

- 1984: New species of Hemiptera Heteroptera from Iraq and the adjacent countries. - Ann. Entomol. Fennici 44:1-59. 
Linnavuori, R. E. 1986: Heteroptera of Saudi Arabia. Fauna of Saudi Arabia 8:31-197.

- 1989: New taxa of Heteroptera and Auchenorrhyncha from the Middle East and the Ethiopian Region. Ann. Entomol. Fennici 55:1-9.

Linnavuori, R. E. \& Al-Safadi, M. M. 1993: New species of Miridae (Hemiptera, Heteroptera) from Yemen. Entomol. Fennica 4:179-193.

Schmitz, G. 1970: Contribution à la faune du Congo (Brazzaville). Mission A. Villiers and A. Descarpentries. XCVIII. Hémiptères Miridae et Isometopidae ( ${ }^{\mathrm{re}}$ partie). - Bull. I.F.A.N. 32 Sér. A(3):501-530. 